\title{
PROSES POLITIK DALAM PENYEBARAN GAGASAN TRANSPARANSI INDUSTRI EKSTRAKTIF DI INDONESIA
}

\author{
Political Process in The Dissemination of Extractive Industries Transparency in Indonesia
}

\author{
Regina Anjani Karissaputri \\ Departemen Ilmu Hubungan Internasional, Universitas Indonesia \\ Alamat email: reginanjani@gmail.com
}

Naskah Diterima: 29 Agustus 2017

Naskah Direvisi: 16 November 2017

Naskah Diterima: 22 November 2017

\begin{abstract}
Transparency is perceived as a main prerequisite to achieve good governance. This include transparency for extractive industries, that regulates the disclosure of oil, gas and mining revenue report to public, with expected purposeto rescue developing countries from 'resource curse'. However, the general acceptance of such practice does not just happen. It has undergone a complex political process to finally form a common view. This paper analyzes the idea of transparency in extractive industry from its dissemination to the adoption and implementation in Indonesia from critical perspective. The author uses Gramscian perspective to explain the political process in the promotion of the idea through the framework of intellectual hegemony. With Gramscian perspective, this paper breaks down the configuration of actors that establish, construct, and promote the idea of transparency in extractive industries; and analyzes the embedded interests in the implementation in Indonesia.
\end{abstract}

Keyword: EITI, good governance, extractive industries transparency, gramsci, hegemony

\begin{abstract}
Abstrak
Transparansi, saat ini, dipercaya dan berkembang sebagai suatu best practice untuk mencapai tata kelola pemerintahan yang baik (good governance). Termasuk transparansi bagi industri ekstraktif, khususnya minyak, gas, dan tambang yang diterima sebagai solusi paling efektif untuk 'menyelamatkan' negara-negara berkembang dari buruknya tata kelola mereka (resource curse). Meskipun begitu, diterimanya transparansi industri ekstraktif sebagai solusi menjalankan pemerintahan yang baik tidak terjadi begitu saja. Terciptanya pandangan umum bahwa transparansi industri ekstraktif merupakan prasyarat pemerintahan yang baik telah melalui proses politik yang dapat ditelusuri. Tulisan ini mencoba melihat dari sudut pandang kritis penyebaran gagasan transparansi industri ekstraktif hingga adopsi dan implementasinya di Indonesia. Penulis menggunakan perspektif Gramscian untuk melihat proses politik berupa hegemoni intelektual dalam penyebaran gagasan transparansi industri ekstraktif. Penulis memfokuskan analisis pada lima fitur hegemoni intelektual Robert Cox, kemudian melihat proses pembentukan blok historis serta penyebaran gagasan oleh blok historis. Tulisan ini akan memperlihatkan proses perkembangan gagasan transparansi industri ekstraktif serta peran berbagai aktor didalamnya hingga mencapai adopsi dan implementasi di Indonesia.
\end{abstract}

Kata kunci: EITI, extractive industries transparency initiative, good governance, transparansi, transparansi industri ekstraktif, gramsci, hegemoni

\section{PENDAHULUAN}

Transparansi industri ekstraktif telah berkembang sebagai norma global baru yang diterima secara luas dan dipercaya merupakan sebuah solusi untuk menyelamatkan negara- negara yang menggantungkan pemasukannya dari sumber daya alamnya. Penerapan transparansi industri ekstraktif pada tataran global dilembagakan dalam Extractive Industries Transparency Initiative (EITI) yang dimulai 
pada tahun 2003. EITI menerbitkan laporan penerimaan negara dari sektor minyak dan gas (migas) serta mineral dan batu bara (minerba) dari hasil audit laporan lembaga pemerintah serta laporan perusahaan yang terlibat.

Pendukung gagasan ini percaya bahwa transparansi industri ekstraktif merupakan solusi bagi resource curse atau dikenal juga sebagai paradox of plenty. ${ }^{1}$ Resource curse sendiri diartikan sebagai permasalahan umum negaranegara yang kaya akan sumber daya alam dimana kekayaannya tersebut tidak dikelola secara bijak hingga menghasilkan berbagai permasalahan bagi negara. ${ }^{2}$ Menurut pendukung gagasan ini, transparansi industri ekstraktif dapat meningkatkan kualitas pengelolaan sumber daya alam, mengurangi korupsi, hingga memitigasi konflik. ${ }^{3}$ Pendapat yang mendukung gagasan ini berhasil membentuk konsensus umum untuk menjadikan transparansi industri ekstraktif sebagai parameter pemerintahan yang baik. Sebagai penilai baik buruknya kredibilitas negara, transparansi industri ekstraktif menjadi prasyarat pinjaman luar negeri kepada berbagai institusi keuangan internasional.

Melihat lebih jauh, diterimanya gagasan transparansi industri ekstraktif tidak terjadi begitu saja. Gagasan transparansi industri ekstraktif disebarkan melalui proses kampanye global dan melibatkan berbagai aktor internasional dalam pembentukan agendanya. Penyebaran ide transparansi industri ekstraktif melibatkan proses koalisi organisasi internasional dan aktor domestik untuk dapat mencapai tahap adopsi oleh negara. Mengutip

Richard M. Auty, "Industrial Policy Reform in Six Large Newly Industrializing Countries: The Resource Curse Thesis." World development 22, no. 1 (1994): 11-26; baca juga Kirk Hamilton \& Giovanni Ruta, "From Curse to Blessings", Environment Matters 2006-The World Bank Group, 2006, diakses 14 November 2017, http:// siteresources.worldbank.org/INTENVMAT/641999551162240805462/21125342/9FromCurse.pdf.

Nigeria's, E. I. T. I. dan Mary Ella Keblusek, "Is EITI Really Helping Improve Global Good Governance?", (2010), 3

Evi Fitriani, Francisia SSE Seda, dan Yesi Maryam, Governance of Extractive Industries: Assessing National Experiences to Inform Regional Cooperation in Southeast Asia (UIP, 2014), 20. perkataan Risse, sebuah ide tidak hanya 'float freely', melainkan dibentuk dan ditransmisikan oleh aktor-aktor tertentu. Haufler juga berpendapat bahwa suksesnya penyebaran gagasan transparansi industri ekstraktif dapat terjadi karena difasilitasi oleh konfigurasi normatif global era neoliberal. Kesesuaian gagasan ini dengan konsensus umum tujuantujuan liberal mempermudah lobi politik yang terjadi diantara aktor-aktor yang terlibat di dalam sistem.

Pendapat Risse dan Haufler tersebut sebenarnya telah lebih dahulu dibahas oleh diskursus-diskursus Gramscian mengenai hegemoni intelektual. Gramsci percaya bahwa perkembangan norma tidak terlepas dari proses penanaman ide oleh pihak yang kuat kepada pihak yang lemah pada suatu struktur. Gramsci mempercayai ada hegemoni intelektual pada struktur masyarakat. Pemahaman ini dijelaskan kembali oleh Robert Cox yang mengaplikasikan pemikiran Gramsci pada tataran hubungan internasional. Menurut Robert Cox, dalam tatanan dunia, pihak-pihak dengan ekonomi yang kuat akan membentuk doktrindoktrin ekonomi untuk mempertahankan supremasinya. ${ }^{4}$ Dengan kata lain, pihak dengan ekonomi kuat mampu membentuk dan menyebarkan ideologi universal yang akan diikuti oleh pihak lainnya untuk bertahan dalam sistem.

Keadaan tersebut menegaskan bahwa adopsi gagasan transparansi industri estraktif tidak dapat diterima begitu saja. Ada proses politik yang dapat ditelusuri hingga gagasan tersebut diadopsi oleh negara. Bagaimana sebuah norma global dapat terbentuk, diterima, dan dijalankan oleh negara? Apakah gagasan transparansi industri ekstraktif benar dijalankan untuk menyejahterakan negara berkembang atau merupakan bagian dari agenda untuk mempertahankan kekuatan ideologis pihak tertentu?

Robert W Cox, Production, Power, and World Order: Social Forces in the Making of History Vol. 1. (Columbia: Columbia University Press, 1987),107-109. 


\section{PERKEMBANGAN EITI DAN IMPLEMENTASINYA DI INDONESIA}

Indonesia memutuskan untuk mengadopsi EITI pada tahun 2010 melalui Peraturan Presiden (Perpres) Nomor 26 Tahun 2010 mengenai transparansi penerimaan negara dan pendapatan daerah yang diperoleh dari industri ekstraktif. Meskipun begitu, pembicaraan mengenai gagasan ini telah dimulai sejak tahun 2001 ketika Menteri Lingkungan Hidup dan Kependudukan Indonesia saat itu, Prof. Emil Salim diangkat menjadi ketua untuk Extractive Industries Review (EIR). EIR merupakan prakarsa presiden Grup Bank Dunia, Mr. James Wolfensohn, sebagai respon terhadap banyaknya kritik dari organisasi masyarakat sipil terhadap keikutsertaan Bank Dunia dalam perumusan dan pendanaan proyekproyek yang berhubungan dengan industri ekstraktif, khususya migas dan minerba. Pada tahun 2003, EIR mengeluarkan laporannya, namun tidak mendapatkan respon yang positif dari publik. Laporan EIR yang dikeluarkan pada tahun 2003 kembali mendapatkan banyak kritik dari berbagai lembaga, terutama organisasi masyarakat sipil karena dianggap tidak menghasilkan perubahan dari keadaan semula, dimana Bank Dunia masih diberi ruang untuk menyampuri urusan industri migas dan minerba. ${ }^{5}$ Meskipun banyak dikritik, EITI tetap dijalankan sebagai respon dan implementasi dari EIR.

EITI dicetuskan oleh Perdana Menteri Inggris Tonny Blair pada World Summit for Sustainable Development di Johannesburg, Afrika Selatan, September 2002. ${ }^{6}$ Bank Dunia kemudian memfasilitasi implementasi EITI di berbagai negara. Bank Dunia melakukan pendekatan kepada korporasi-korporasi minyak internasional (IOC) serta organisasi-organisasi masyarakat sipil (NGO) dalam mempromosikan pentingnya aspek transparansi dan akuntabilitas sektor ESDM, termasuk di Indonesia. Bank

\footnotetext{
5 Dalal-Clayton, Barry, dan Barry Sadler, Sustainability appraisal: a sourcebook and reference guide to international experience, (London: Routledge, 2014), 552.

6 Clayton, Sustainability Appraisal, 552.
}

Dunia juga membuka Multi Donor Trust Fund (MDTF) untuk mendukung implementasi EITI dan transparansi yanglebih luas dinegara-negara pemilik sumber daya ekstraktif kaya. ${ }^{7}$ MDTF menjadi lembaga yang memberikan pinjaman dana untuk kebutuhan awal implementasi EITI, seperti untuk pelatihan dan penyuluhan kepada berbagai stakeholders, pembangunan sistem, hingga pembangunan headquarter. ${ }^{8}$ Demikian Bank Dunia menawarkan ide transparansi industri ekstraktif tersebut lengkap dengan keseluruhan perangkat mekanisme teknis dan peraturan, alur negosiasi, hingga pendanaan untuk pendirian headquarter.

Perkembangan EITI di Indonesia didahului oleh masuknya suatu Lembaga Swadaya Masyarakat (LSM) bernama PWYP pada tahun 2007, sebelum dimulainya negosiasi Bank Dunia dengan pemerintah Indonesia pada tahun 2008. PWYP Indonesia berafiliasi dengan PYWP internasional yang memiliki tujuan untuk mendorong perusahaan-perusahaan tambang untuk membuka data pembayarannya kepada pemerintah. PWYP sendiri merupakan prakarsa George Soros yang menggabungkan 5 NGO yang telah berdiri, yakni Global Witness, CAFOD, Oxfam, Save the Children UK, dan Transparency International UK. ${ }^{9}$ PWYP juga dibentuk dalam World Summit for Sustainable Development bersama dengan prakarsa pendirian EITI untuk menyertai penyebaran EITI di berbagai negara. Lebih jauh, PWYP Indonesia menjadi perwakilan masyarakat sipil yang berhak memilih 3 orang anggota dalam tim pelaksana EITI Indonesia.

Pada bulan Agustus 2008, IMF memberi saran kepada pemerintah Indonesia untuk mengadopsi EITI dalam rangka memperkuat performa fiskal pemerintah Indonesia melalui konsultasi Article IV. ${ }^{10}$ Article IV sendiri

\footnotetext{
Clayton, Sustainability Appraisal,141.

Clayton, Sustainability Appraisal, 141.

Mabel van Oranje dan Henry Parham, "Publishing What We Learned", assesment of the Publish What You Pay Coalition (2009), 32.

10 International Monetary Fund, "Indonesia : 2008 Article IV Consultation- Staff Report; Staff Statement; Public Information Notice on the Executive Board Discussion;
} 
merupakan bentuk komunikasi pemerintah Indonesia dengan IMF untuk mengevaluasi kebijakan-kebiakan makro ekonomi yang dijalankan oleh pemerintah Indonesia. Pada Desember 2008, Pemerintah Indonesia menyatakan komitmennya untuk menjalankan tahapan dan syarat-syarat untuk menjadi negara kandidat EITI. ${ }^{11}$ Sejak saat itu, Bank Dunia turut memainkan perannya dalam implementasi EITI di Indonesia dengan memfasilitasi dialog multistakeholder maupun mempersiapkan kebutuhan-kebutuhan biaya yang akan muncul. Bank Dunia memfasilitasi forum dialog antara pemerintah, pebisnis, dan masyarakat sipil sebagai aktor dalam EITI, memberikan asistensi teknis, serta memenuhi biaya-biaya yang diperlukan dalam proses pengimplementasian EITI di Indonesia melalui mekanisme Multi Donor Trust Fund (MDTF). ${ }^{12}$

Pada tahun 2008, diterbitkanlah Instruksi Presiden Nomor 5 Tahun 2008 yang menempatkan poin transparansi pendapatan industri minyak dan pertambangan didalamnya. Inpres tersebut didorong oleh Kementerian Koordinator Perekonomian yang pada saat tersebut dipimpin oleh Boediono dan kemudian diteruskan oleh Sri Mulyani. ${ }^{13}$ Inpres ini mendorong dikeluarkannya Peraturan Presiden Nomor 26 Tahun 2010 yang memulai penerapan EITI di Indonesia. Sekretariat EITI Indonesia mulai menerbitkan laporannya sejak tahun 2009, untuk memenuhi syarat mendapatkan predikat candidate country. Hingga saat ini EITI telah menerbitkan 4 laporan, yakni

and Statement by the Executive Director for Indonesia', IMF Country Report No. 08/299, 2008, diakses 30 Mei 2017, https://books.google.co.id/books?id=VuqTEI_DW $\mathrm{E} 4 \mathrm{C} \& \mathrm{pg}=\mathrm{PA} 58 \& \mathrm{lpg}=\mathrm{PA} 58 \& \mathrm{dq}=\mathrm{eiti}+$ indonesia +200 $8 \&$ source $=$ bl\&ots $=$ Wmxd_HBDSM\&sig $=y$ U9H4 $-7 \mathrm{LZ}$ HkZGSXzepqarVJHT1g\&hl=en\&sa $=$ X\&ved $=0$ ahUKE wiFyvOJOa_TAhULpI8KHRSQBaUQ6AEITDAH\# $\mathrm{v}=$ onepage\&q\&f=false.

11 EITI Organization, "Southeast Asia Warming Up to EITI”, diakses 23 Februari 2017, https://eiti.org/blog/ southeast-asia-warming-up-to-eiti

12 Susan Ariel Aaronson, "Limited partnership: Business, government, civil society, and the public in the Extractive Industries Transparency Initiative (EITI)". Public Administration and Development 31, no. 1 (2011): 50.

13 Penjelasan lebih lanjut pada Bab III. laporan tahun 2009, laporan tahun 2010. 2011, laporan tahun 2012-2013, serta laporan tahun 2014 yang terbit pada 28 Februari 2017. Dalam menerbitkan laporannya, Indonesia juga mengikuti standar EITI internasional yang semakin kompleks dalam pelaporannya.

\section{KERANGKA KONSEP}

Tulisan ini menggunakan perspektif Gramscian untuk menganalisis proses politik yang terjadi dalam penerimaan gagasan transparansi industri ekstraktif di Indonesia. Fokus teori Gramscian adalah pada hegemoni ideologi dimana legitimasi terhadap kekuasaan tidak lagi diperoleh menggunakan cara koersif, melainkan melalui penanaman ideologi untuk mencapai perilaku yang sejalan dengan sistem. Konsep hegemoni Gramsci banyak diartikan sebagai hegemoni organik atau hegemoni intelektual karena bagi Gramsci, kekuasaan bukan ditegakkan secara koersif melainkan secara ideologis. ${ }^{14}$ Dalam membentuk pemahaman ideologis maupun membangun instruksi sosial dalam masyarakat, hegemoni menempatkan peran 'intellectuals', yang terdiri dari peran kelompok epistemik atau para ahli, birokrat, pemilik industri, dan politisi. ${ }^{15}$ Dalam operasionalisasi hegemoni, 'intellectuals' tersebut akan menjadi bagian dari suatu aliansi yang disatukan secara politis oleh seperangkat ide hegemonik untuk mempromosikan ideologi. Struktur ini disebut Gramsci sebagai blok historis.

Proses pembentukan hegemoni ini dijalankan paling efektifmelaluimekanismeyang dilembagakan melalui institusi internasional dimana institusi tersebut berperan untuk mengembangkan ideologi hegemoni kepada negara. Diperjelas oleh Robert Cox, institusi internasional menjalankan peran hegemoninya melalui 5 fitur, yakni, 1) institusi menginisiasi peraturan yang memfasilitasi ekspansi hegemoni dalam tata dunia, 2) institusi tersebut

\footnotetext{
14 Robert W. Cox, "Gramsci, hegemony and international relations: an essay in method." Millennium 12, no. 2 (1983), 133.

15 Cox, "Gramsci, Hegemony, and International Relations", 132.
} 
juga merupakan produk hegemoni, 3) institusi secara ideologis mengesahkan norma-norma tatanan dunia, 4) institusi mengkooptasi elitelit negara periferal, dan 5) institusi menyerap ide-ide kontra hegemoni. ${ }^{16}$ Kelima fitur ini akan menjadi acuan analisis dalam melihat bagaimana hegemoni intelektual ditransmisikan dalam promosi dan implementasi gagasan transparansi industri ekstraktif di Indonesia.

\section{Fitur-Fitur Hegemoni Intelektual Dalam Institusionalisasi EITI \\ Institusi Menginisiasi Peraturan yang Memfasilitasi Ekspansi Hegemoni dalam Tata Dunia}

Dalam menjelaskan fitur ini, Cox berargumen bahwa institusi internasional akan menerbitkan peraturan untuk memfasilitasi ekspansi kekuatan ekonomi dan sosial yang dominan. Cox menggunakan contoh dimana peraturan untuk sistem moneter dan perdagangan dunia dibingkai oleh gagasan untuk mempromosikan ekspansi ekonomi dengan mempertahankan prinsip-prinsip yang selaras dengan kepentingan sistem liberal. ${ }^{17}$

Penyebaran gagasan transparansi industri ekstraktif didukung oleh argumen bahwa transparansi akan meningkatkan investasi bagi negara-negara berkembang. Hal ini juga merupakan salah satu prinsip yang dibawa oleh EITI yakni kepercayaan bahwa transparansi akan mendorong peningkatan kualitas iklim investasi domestik sehingga akan membawa pengaruh positif pada peningkatan investasi luar negeri. ${ }^{18}$ Dengan kata lain, prakarsa transparansi industri ekstraktif melalui EITI, yang ditujukan untuk diterapkan oleh negara berkembang, akan memberikan ruang yang lebih terjamin bagi perusahaan-perusahaan dari negara maju untuk berinvestasi. Peningkatan terhadap investasi asing yang ditawarkan kepada negara berkembang sebagai reward dari

\footnotetext{
16 Cox, "Gramsci, Hegemony, and International Relations", 137.

17 Cox, "Gramsci, Hegemony, and International Relations", 138.

18 EITI Organization, "Prinsip-Prinsip EITI", diakses 5 Mei 2017, https://eiti.org/document/eiti-principles.
}

melakukan transparansi bukanlah keuntungan bagi negara berkembang semata, namun juga merupakan keuntungan bagi negara maju untuk memperluas jangkauan investasinya, termasuk dalam bidang industri ekstraktif.

Penelitian terhadap 81 negara yang menerapkan EITI sejak tahun 2004 hingga 2011 membuktian bahwa menjadi EITI candidate country meningkatkan rata-rata tingkat investasi luar negeri terhadap total GDP sebanyak 2\%. ${ }^{19}$ Peningkatan 2\% tersebut terbilang signifikan karena kontribusi investasi luar negeri terhadap GDP dari negara-negara yang diteliti rata-rata adalah 4\%, sehingga dapat dikatakan bahwa EITI mampu meningkatkan investasi luar negeri hingga 50\%. Salah satu negara yang dinyatakan mengalami peningkatan investasi luar negeri secara signifikan setelah menerapkan EITI adalah Kazakhstan. Negara ini mengimplementasikan EITI sejak tahun 2007 dan merupakan salah satu negara Asia pertama yang mendapatkan status EITI compliant. ${ }^{20}$ Data IMF menunjukkan bahwa kontribusi investasi luar negeri terhadap GDP Kazakhstan meningkat hingga 230\% sampai tahun 2011 dengan peningkatan terbesar dari industri migas dan minerba yang mencapai 125\% terhitung dari tahun 2009. ${ }^{21}$ Investasi asing di Kazakhstan didominasi oleh perusahaan migas dari Belanda, Amerika Serikat, Inggris, Perancis, \& Tiongkok. Hingga tahun 2015, 70\% ekstraksi minyak dan gas di Kazakhstan dikuasai oleh investor luar negeri. ${ }^{22}$

19 Maya Schmaljohann, "Enhancing Foreign Direct Investment via Transparency? Evaluating the Effects of the EITI on FDI". No. 538. Discussion Paper Series, University of Heidelberg, Department of Economics (2013), 18.

$20 \quad$ EITI Organization, "EITI in Kazakhstan, Kyrgyzstan and possibly Tajikistan”, diakses 5 Mei 2017, https:/eiti.org/ blog/eiti-in-kazakhstan-kyrgyzstan-possibly-tajikistan.

21 EITI Organization, "Possibilities for Armenia", diakses 5 Mei 2017, http://crm.aua.am/files/2014/10/EITI-andCSOs.pdf.

22 Sadvakassov, Darmen, and Serik Orazgaliyev, "Key Factors In Attracting Foreign Direct Investments In The Oil And Gas Industry Of Kazakhstan." Aktual'ni Problemy Ekonomiky $=$ Actual Problems in Economics 166 (2015): 147. 
Negara-negara tersebut telah mendukung gagasan EITI sejak konferensi EITI pertama di London pada tahun 2003.23 Data diatas menunjukkan bahwa EITI juga membawa keuntungan material kepada negara yang mendukung gagasan EITI. Peningkatan FDI dari transparansi industri ekstraktif yang seolah menjadi 'buah manis' bagi penerapannya di negara berkembang, sebenarnya juga membawa keuntungan material yang dibutuhkan oleh negara maju. Transparansi pemerintah merupakan komponen yang sejalan untuk menunjang iklim perdagangan yang kondusif yang dibicarakan dalam Putaran Doha pada tahun 2001, yakni non-diskriminasi, transparansi, dan prediktabilitas. Poin transparansi juga merupakan persyaratan perdagangan yang diinginkan oleh negara maju untuk mendukung perdagangan bebas dimana negara tidak mempersulit iklim investasi dengan berbagai pungutan liar. WTO dan OECD juga kerap menekankan bahwa transparansi merupakan aspek penting untuk meningkatkan investasi pasar. Keduanya juga mendorong berbagai perusahaan untuk menjalankan transparansi di bidang industri ekstraktif. Deklarasi negara-negara G8 dalam mendukung EITI juga menyebutkan bahwa transparansi perlu dilakukan karena sesuai dengan Agenda Pembangunan Doha untuk memperoleh transparansi dalam belanja negara. ${ }^{24}$ Bagi negara-negara G8, transparansi merupakan elemen penting untuk memfasilitasi persetujuan perdagangan (trade agreement).

Penjelasan di atas membuktikan bahwa transparansi merupakan elemen penting dalam perdagangan internasional. Data peningkatan FDI dalam bidang industri ekstraktif menggambarkan bahwa gagasan transparansi industri ekstraktif juga berperan dalam memfasilitasi perusahaan-perusahaan besar industri minyak, gas dan tambang dapat memperluas ekspansinya. Hal ini memang

\footnotetext{
23 Van Oranje, "Publishing What We Learned", 57.

24 Japan Ministry of Foreign Affairs, "Fighting Corruption and Improving Transparency: A G8 Declaration", diakses 12 Mei 2017, www.mofa.go.jp/policy/economy/ summit/2003/dec-2.pdf
}

memberikan keuntungan bagi negara tujuan investasi, yang notabene adalah negara berkembang. Namun juga memberikan keuntungan lebih besar bagi perusahaanperusahaan besar dan negara-negara maju pemilik perusahaan-perusahaan tersebut. Pada akhirnya, gagasan EITI juga merupakan bagian dari usaha negara-negara maju memenuhi permintaan dari perusahaan-perusahaan besar untuk menguasai perdagangan internasional.

\section{Institusi sebagai Produk Hegemoni}

Robert Cox menjelaskan poin ini bahwa institusi internasional dan peraturan pada dasarnya diinisiasi oleh negara, dan oleh karenanya harus mendapatkan dukungan dari negara-negara tersebut. ${ }^{25}$ Pola demikian juga dapat dilihat melalui partisipasi G8 dan negaranegara pendukung EITI (EITI supporting countries) yang mendukung sejak awal tanpa menganggotai EITI.

Group of Eight atau G-8, organisasi negaranegara maju yang beranggotakan Perancis, Inggris, Amerika Serikat, Kanada, Jepang, Jerman, Rusia, dan Italia menerbitkan "Fighting Corruption and Improving Transparency", suatu deklarasi yang memprioritaskan transparansi pada industri ekstraktif pada bulan Juni 2003.26 Kedelapan negara maju tersebut kemudian mendukung, namun belum memutuskan untuk menjalankan standar EITI. Amerika Serikat menjadi negara G8 pertama yang memutuskan untuk menjalankan standar EITI pada tahun 2014 meskipun saat ini telah memutuskan untuk keluar dari keanggotaan EITI pada Maret 2017. Peran G8 mendukung EITI dapat dilihat dari keberpihakannya pada transparansi pendapatan negara yang dikemukakan pada dokumen Fighting Corruption and Improving Transparency.

Meskipun begitu, dokumen tersebut memperlihatkan bahwa fokus transparansi dan akuntabilitas yang direncanakan oleh G8 bukanlah untuk mengatur negara-negara

\footnotetext{
25 Cox, "Gramsci, Hegemony, and International Relations", 138.

26 World Bank, EITI Implementation Report 2010 (World Bank: February 2010), 4.
} 
G8, melainkan negara-negara berkembang. Poin-poin yang terkandung ditujukan untuk mendorong penerapan regulasi ini oleh negara berkembang, sementara negara-negara G8 beserta Bank Dunia dan IMF akan menjalankan fungsi asistensi dan pendanaan. Fokus pendanaan negara-negara G8 ditujukan kepada negara-negara berkembang yang menempatkan transparansi dan good governance sebagai prioritas kebijakannya, dengan menempatkan IMF \& Bank Dunia sebagai pendukung implementasinya (poin 1.1).

Mendukung tanpa mengimplementasikan ini juga diperlihatkan dalam pidato Perdana Menteri Inggris, Tony Blair, ketika menginisiasi berdirinya EITI pada Juni 2003. Blair menyampaikan pentingnya transparansi atas penerimaan negara serta manajemen keuangan untuk menjaga akuntabilitas pemerintah dari korupsi. Blair membangun keyakinan negaranegara lainnya untuk menerima gagasan transparansi industri ekstraktif dengan mengatakan bahwa ide tersebut mendapatkan dukungan dari G8 pada pertemuan kepalakepala negara sebelumnya. ${ }^{27}$ Blair mendorong 'komunitas internasional' untuk menyamakan perspektif terhadap prinsip-prinsip transparansi dan good governance, serta memperkuat komitmen untuk mewujudkannya. Meskipun begitu, Inggris tidak langsung menerapkan EITI dan baru menjadi EITI compliant country pada tahun 2014. Hal ini rupanya tidak mengherankan karena dalam pidatonya, Blair sempat mengatakan bahwa bagian 'mereka' adalah mendukung implementasi dengan cara membantu negara-negara yang membutuhkannya.

Aturan atau 'dorongan' G8 kepada negara berkembang akan dilengkapi dengan bantuan dana dan asistensi yang akan dilakukan oleh G8 maupun oleh institusi finansial internasional seperti IMF dan Bank Dunia. G8 telah menguatkan peran Bank Dunia untuk

Tony Blair, "Extractive Industries Transparency Initiative", (pidato, Johannesburg, Afrika Selatan, 17 Juni 2003), Europe Archive, diakses 30 Juli 2017, http:// collections.europarchive.org/tna/20070701080507/http:/ www.dfid.gov.uk/pubs/files/eitidraftreportspeech.pdf. masuk ke dalam reformasi pemerintahan negara berkembang dalam rangka meningkatkan akuntabilitas. Hal tersebut juga memperlihatkan bagaimana negara-negara G8 telah menyiratkan negara-negara berkembang untuk tidak menolak gagasan yang dibawa oleh Bank Dunia kepada mereka. Selain bantuan material, G8 juga mendorong Bank Dunia untuk memberikan asistensi teknis kepada negara yang menerapkan transparansi migas dan minerba. Asistensi teknis juga akan mencakup cara-cara pembuatan format laporan sesuai dengan aturan dan penilaian yang dirumuskan oleh institusi finansial internasional. ${ }^{28}$

Gagasan yang dibawa oleh negaranegara G8 tersebut tertuang dalam pidato pembentukan EITI yang disampaikan oleh Tony Blair maupun dalam prinsip-prinsip dasar EITI. Setidaknya ada 4 kesamaan poin pandangan G8, pandangan Tony Blair sebagai penggagas EITI, dan pandangan EITI yang pada akhirnya membentuk ideologi dan konsensus umum terkait transparansi industri ekstraktif. Keempat poin tersebut adalah 1) Argumen bahwa transparansi pendapatan dan manajemen keuangan yang lebih baik merupakan kunci mencegah korupsi dan kesalahan manajemen negara-yang menyebabkan lambatnya pembangunan ekonomi; 2) Argumen bahwa transparansi merupakan cara terbaik untuk mencapai akuntabilitas; 3) Transparansi merupakan bagian dari misi besar pengentasan kemiskinan global; dan 4) Transparansi mampu mendorong pembangunan ekonomi (melalui peningkatan investasi luar negeri).

Promosi norma besar-besaran oleh negaranegara maju berhasil menjadikan transparansi industriekstraktifsebagaiparameter'wargadunia yang baik' dalam sistem internasional. Negaranegara maju tersebut kemudian memberikan legitimasi kepada institusi internasional untuk mengimplementasikan gagasan tersebut meluas ke negara-negara berkembang. Dapat dikatakan bahwa nilai-nilai yang dijalankan oleh institusi internasional bersumber dari ideide yang dibawa oleh sekelompok negara-negara

28 Transparency Initiative, “GPR.” (2011). VI. 
tertentu yang mampu memberikan tidak hanya dukungan material, tetapi juga kekuasaan untuk mengatur bagi institusi internasional untuk menjalankannya.

\section{Peran Ideologis Institusi dalam Mengesahkan Tatanan Dunia}

Penerimaan transparansi sebagai tolok ukur negara sebagai warga dunia yang baik merupakan sebuah kemenangan ideologis yang dipengaruhi oleh kompleksitas kekuasaan institusi internasional. Menurut Finel dan Lord, dorongan kuat terhadap gagasan transparansi diawali oleh krisis finansial yang kemudian membangkitkan inisiatif dan tekanan Bank Dunia akan perluasan transparansi sebagai prasyarat peminjaman modal. ${ }^{29}$ Dikerucutkan pada ranah politik internasional, Finel dan Lord menjelaskan bahwa gagasan transparansi tumbuh dari dorongan IMF dan US Treasury Department yang memberikan pandangan pada saat krisis terjadi bahwa satu-satunya jalan untuk mengembalikan kepercayaan investor di Asia adalah dengan melakukan transparansi. Hal ini juga kemudian diafirmasi oleh pemimpin-pemimpin di Asia dimulai oleh perdana menteri Singapura pada saat itu, Lee Kuan Yew. ${ }^{30}$

Institusi internasional juga menerbitkan berbagai publikasi yang mendukung gagasan resource curse sembari berusaha meredam gagasan-gagasan yang kontra. Tugas MDTF Bank Dunia selain mendanai berbagai proyek kerjasama, juga membangun pengetahuan dan pandangan masyarakat melalui berbagai publikasi. Bank Dunia memposisikan dirinya sebagai 'key knowledge producer'. ${ }^{31}$ Grup Bank Dunia menghasilkan banyak produk-produk penelitian dalam bidang industri ekstraktif, mulai dari sekadar hasil diskusi hingga berbagai hasil studi formal pada isu-isu bertema gender, pemerintahan, reformasi, dan sebagainya.

29 Finel, Bernard, and Kristin Lord, Power and Conflict in the Age of Transparency. (New York: Springer, 2002), 3.

30 Lord, Power and Conflict, 20-21.

31 EITI Organization, "Joint Review, EITI and EITI Mutlidonor Trust Fund Resourcing of the EITI", diakses $20 \mathrm{Mei}$ 2017 https://eiti.org/sites/default/files/.../2015_ScanteamReview_EITI-Funding.pdf.
World Bank Institute, bagian internal dalam Grup Bank Dunia, juga memprakarsai GOXI website pada November 2013, bekerja sama dengan United Nations Development Programme (UNDP). GOXI website sendiri diartikan sebagai tempat berdialog dan wadah untuk berinovasi dan berkolaborasi bagi pihak-pihak dalam pemerintahan yang bergerak pada bidang industri ekstraktif.32 Pada Laporan tahun 2015, MDTF telah mengeluarkan dana sebanyak USD 4,1 juta untuk pengembangan publikasi dan berbagai aktivitas pengembangan pengetahuan dan pembelajaran. MDTF juga mendanai proyek-proyek organisasi masyarakat sipil yang pada laporan tahun 2015, telah terserap sebanyak USD 3,2 juta.

Bank Dunia, melalui Open Knowledge Repository-nya, telah menerbitkan 82 publikasi yang mendukung gagasan mengenai resource curse terhitung tahun 2011 hingga 2017 dengan rincian 23 publikasi dari Bank Dunia dan 59 publikasi lainnya dari penulis lepas maupun akademisi dengan pendanaan dari Bank Dunia. ${ }^{33}$ Publikasi tentang manajemen sumber daya migas dan minerba yang mempromosikan EITI tidak hanya diterbitkan oleh Bank Dunia. Setidaknya ada lembaga donor seperti Natural Resource Governance Institute (NRGI, dahulu Revenue Watch Institute atau RWI), lembaga riset seperti Institute for Essential Services Reform (IESR), dan PWYP yang secara aktif mengeluarkan publikasi terkait dengan industri ekstraktif dari sudut pandang yang sejalan dengan publikasi yang dikeluarkan Bank Dunia. Di Indonesia, NRGI telah mendanai 17 publikasi pada tema industri ekstraktif. ${ }^{34}$ PWYP sendiri telah menerbitkan 112 publikasi terkait dengan tata kelola industri ekstraktif dari berbagai sudut pandang isu. Publikasi tersebut berupa hasil presentasi, infografis, esai, video,

32 GOXI web-site, "About Us”, diakses pada 20 Mei 2017, www.goxi.org/page/about-us.

33 Open Library World Bank, "Open Knowledge Repository", diakses 16 Mei 2017, https://openknowledge.worldbank. org $/$ discover scope $=\% 2 \mathrm{~F} \&$ query $=$ resource + curse $\&$ sub mit.

34 Natural Resoure Governance Institute, "Publications", diakses 16 Mei 2017, https://resourcegovernance.org/ analysis-tools/publications. 
buku, modul, buletin, kertas kebijakan (policy paper), kertas posisi (position paper), review kebijakan, maupun berbagai laporan. ${ }^{35}$ IESR dan NRGI juga merupakan anggota dari PWYP Indonesia.

Banyaknya literatur yang mempromosikan gagasan transparansi industri ekstraktif telah berhasil membentuk pola pikir dan opini masyarakat sejalan dengan cara pandang aktor yang menyebarkannya. Penyebaran ide transparansi industri ekstraktif melalui berbagai literatur dilakukan oleh banyak aktor yang seolah mewakili berbagai kelompok, namun sebenarnya saling berkaitan atau berasal dari sumber yang sama. PWYP sebagai NGO yang terlihat mewakili pandangan masyarakat misalnya, sejak awal dibentuk bersamaan dengan EITI untuk mendorong gagasan yang sama pada tataran global. NRGI dan EISR sendiri juga merupakan anggota dari PWYP yang jelas memiliki pandangan yang sejalan dengan EITI. Kemenangan gagasan transparansi industri ekstraktif juga tidak lepas dari nama-nama besar institusi yang mempromosikannya. Bank Dunia dan IMF masih merajai kiblat kebijakan ekonomi dan pembangunan negara, terutama negara berkembang yang bergantung secara material terhadapnya. Institusi tersebut juga mampu mendikte indikator baik buruknya suatu negara sehingga daripada terkena masalah, negara berkembang akan lebih memilih untuk tunduk. Hal ini menjadi pelumas yang ampuh bagi gagasan transparansi industri ekstraktif untuk berkembang dengan Bank Dunia dan IMF sebagai penopangnya.

\section{Institusi Mengkooptasi Elit-Elit Negara Periferal}

Fitur keempat hegemoni intelektual adalah kooptasi pejabat-pejabat yang menempati posisi tinggi dan berpengaruh dalam pengambilan kebijakan pemerintahan. Tokoh-tokoh tersebut ditarik masuk ke dalam struktur institusi internasional dan kemudian mempromosikan pandangan yang sejalan dengan institusi

\footnotetext{
35 Publish What You Pay Indonesia ,"Publications", diakses 16 Mei 2017, http://pwyp-indonesia.org/id/category/ publikasian/page/11/.
}

yang menariknya. ${ }^{36}$ Pola seperti ini didapati dalam penyebaran gagasan transparansi industri ekstraktif di Indonesia sejak tahun 2001. Ditempatkannya beberapa tokohtokoh pemerintah yang cerdas dan memiliki performa baik dalam jabatan-jabatan tinggi pemerintahan dalam struktur Bank Dunia telah menyukseskan diterimanya gagasan ini dalam lingkup pemerintahan. Tokoh-tokoh tersebut diantaranya adalah pertama, Prof. Emil Salim, Menteri Lingkungan Hidup dan Kehutanan pada saat itu, yang juga menjadi eminent person atau ketua dari Extractive Industries Review (EIR). Tokoh kedua adalah bapak Boediono, pada saat itu menjabat sebagai Menteri Koordinator Bidang Perekonomian, yang menjadi World Bank Group Governor. Ada beberapa tokoh kunci lainnya, akan tetapi pembahasan ini akan difokuskan kepada Prof. Emil Salim dan Boediono karena penulis rasa memiliki andil paling signifikan terhadap diterimanya gagasan transparansi industri ekstraktif oleh pemerintah Indonesia.

Penerapan EITI di indonesia tidak terlepas dari formulasi EIR pada tahun 2001. EIR diinisiasi oleh Bank Dunia dengan menunjuk Prof. Emil Salim, sebelumnya merupakan Menteri Lingkungan Hidup dan Kependudukan Indonesia, untuk menjadi ketuanya. ${ }^{37}$ Sekilas mengenai EIR, EIR merupakan prakarsa presiden Grup Bank Dunia, Mr. James Wolfenson, sebagai respon terhadap banyaknya krtik dari organisasi masyarakat sipil terhadap keikutsertaan Bank Dunia dalam perumusan dan pendanaan proyek-proyek yang berhubungan dengan industri ekstraktif, khususya migas dan minerba. Tujuan EIR yang Wolfenson berikan kepada Prof. Emil Salim adalah untuk mengkaji apakah proyek-proyek industri ekstraktif dapat berjalan sejalan dengan tujuan WBG terkait poin pembangunan berkelanjutan dan eliminasi korupsi.

\footnotetext{
36 Cox, "Gramsci, Hegemony, and International Relations", 139.

37 Gita Widya Laksmini, Maryati Abdullah, et.all, "EITI in Indonesia: A Multi-Stakeholder Advocacy”, RWI-USAID IKAT US Project, (2012): 2.
} 
Pada tahun 2003, EIR mengeluarkan laporannya, namun tidak mendapatkan respon yang positif dari publik. Kritik datang dari berbagai lembaga, terutama organisasi masyarakat sipil karena dianggap tidak menghasilkan perubahan dari keadaan semula, dimana Bank Dunia masih diberi ruang untuk menyampuri urusan industri migas dan minerba. ${ }^{38}$ Pada tahun 2004, WBG justru memprakarsai MDTF yang menghimpun lembaga-lembaga donor untuk implementasi EITI di negara berkembang. ${ }^{39}$ Meskipun ada ketidaksetujuan, terutama dari negara-negara berkembang, mengenai campur tangan Bank Dunia dalam ranah ekstraktif, Bank Dunia tetap mendanai EITI.

Di Indonesia sendiri pada tahun 2003, ketika EIR mempublikasikan laporannya dan mendapatkan banyak kritikan, Boediono, yang pada saat itu menjabat sebagai Menteri Keuangan dan juga WBG Governor, merilis pernyataan atas nama pemerintah Indonesia untuk mendukung implementasi dari rekomendasi EIR. ${ }^{40}$ Penerimaan terhadap EITI kemudian mendapatkan titik terang seiring terpilihnya Presiden Susilo Bambang Yudhoyono yang mengutamakan agenda antikorupsi, transparansi, dan good governance. Pada tahun 2006, pimpinan EITI board internasional yang juga merupakan penggagas Transparency International (TI), Peter Eigen, datang ke Indonesia untuk berbicara dengan Presiden Susilo Bambang Yudhoyono. ${ }^{41}$ Kedatangan Eigen ini rupanya mampu memberikan pelumas bagi persetujuan EITI, terlihat dari rancangan Peraturan Presiden untuk mengimplementasikan EITI mulai disiapkan.

Pada tahun 2008, diselengarakanlah Rapat Koordinasi tentang EITI dipimpin oleh Boediono yang pada saat itu menjabat sebagai Menteri Koordinator Bidang Perekonomian (Menko Perekonomian). Tercapailah

\footnotetext{
38 Dalal-Clayton, Barry, and Barry Sadler, Sustainability appraisal: a sourcebook and reference guide to international experience (London: Routledge, 2014), 552.

39 Laksmini \& Abdullah, "EITI in Indonesia", 17.

40 Laksmini \& Abdullah, "EITI in Indonesia", 3.

41 Laksmini \& Abdullah, "EITI in Indonesia”, 5.
}

kesepakatan pembentukan Tim Pengarah EITI dipimpin oleh Menko Perekonomian, Menteri Energi dan Sumber daya Mineral, dan Menteri Keuangan. Pada akhir tahun, Kemenko Perekonomian mengeluarkan Paket Perubahan Ekonomi dalam Instruksi Presiden No. 5. Tahun 2008 serta MoU dan Peraturan Bersama antara Menteri ESDM dan Menteri Keuangan. Ketiganya berisi aturan kerangka peningkatan transparansi pengelolaan migas dan pertambangan. ${ }^{42}$

Pada Maret 2009, Prof. Emil Salim selaku Dewan Penasihat Presiden bidang Lingkungan Hidup memfasilitasi rapat pembentukan Tim Koordinasi Persiapan Pelaksanaan Transparansi Industri Ekstraktif. Rapat yang membahas rencana kerja dan biaya EITI Indonesia tersebut dihadiri oleh kepala EITI internasional, Kepala Bank Dunia untuk EITI global, serta kepala Bank Dunia untuk penerapan EITI di Asia. Kemudian pada Januari 2010, Kementerian Koordinator bidang Perekonomian menyerahkan usulan terakhir (final) Peraturan Presiden kepada Sekretariat Kabinet. ${ }^{43}$ Pada tanggal 23 April dikeluarkanlah Peraturan Presiden No. 26/2010 tentang Transparansi Pendapatan Negara dan Pendapatan Daerah yang diperoleh dari Industri Ekstraktif, ditandatangani oleh Presiden RI saat itu, Susilo Bambang Yudhoyono. Undang-Undang nomor 26 Tahun 2010 tentang Transparansi Pendapatan Negara Dan Pendapatan Daerah Yang Diperoleh Dari Industri Ekstraktif menjadi tonggak diadopsinya gagasan transparansi industri ekstraktif diterima di Indonesia sehingga Indonesia mendapatkan status EITI candidate country.

Peraturan Presiden no 26 tahun 2010 menetapkan susunan tim pengarah EITI yang terdiri dari Menteri Koordinator Bidang Perekonomian sebagai koordinator. Kemudian

42 Badan Pengawas Keuangan dan Pembangunan, "Instruksi Presiden nomor 5 tahun 2008 tentang Fokus Program Ekonomi tahun 2008-2009", diakses 21 Mei 2017, www. bpkp.go.id/uu/filedownload/7/24/37.bpkp.

43 Azi Nur Alam, "Kepentingan World Bank dan Pemerintah Indonesia dalam Proses Pengimplementasian Extractive Industries Transparency Initiative (EITI)", (Program Studi S2, Universitas Indonesia, 2010), 67. 
dianggotai oleh Menteri Energi dan Sumber Daya Mineral, Menteri Keuangan, Menteri Dalam Negeri, Kepala Badan Pengawas Keuangan dan Pembangunan, serta Prof. Dr. Emil Salim. ${ }^{44}$ Susunan tersebut terasa janggal dengan adanya nama Prof. Emil Salim diantara anggota tim pengarah lainnya yang dideskripsikan dalam jabatan struktural. Meskipun begitu, hal tersebut tidak banyak dipertanyakan karena Prof. Emil Salim diakui sebagai champion dalam implementasi EITI di Indonesia oleh kalangan pemerintah. Istilah champion merujuk pada pengertian individu yang menduduki posisi terhormat dalam pemerintahan yang setuju dengan konsep EITI dan memberikan komitmennya untuk mempromosikan EITI di dalam institusinya maupun kepada kolegakoleganya sesama pejabat pemerintahan. Istilah ini juga muncul dalam publikasi-publikasi yang dikeluarkan PWYP, salah satunya berjudul Digging Up the History.

Dukungan pemerintah Indonesia bagi EITI ditegaskan kembali oleh Boediono, yang pada saat itu adalah Wakil Presiden RI, pada Konferensi tahunan Asosiasi Perminyakan Indonesia (IPA) yang ke-34. Wakil Presiden Boediono menyatakan bahwa "operasionalisasi Peraturan Presiden No. 26/2010 tentang Transparansi Industri Ekstraktif dilaksanakan sesegera mungkin" dan juga bahwa peraturan tersebut adalah satu dari 7 (tujuh) prioritas utama dalam Rencana kerja Energi Nasional Pemerintah. ${ }^{45}$

Melalui kronologis diatas, penulis ingin memperlihatkan bagaimana Bank Dunia menempatkan Prof. Emil Salim dan Boediono dalam jabatan kepemimpinan pada proyekproyek Bank Dunia. Prof. Emil Salim yang pada saat itu merupakan Menteri Lingkungan Hidup dan Kependudukan (saat ini Kementerian Lingkungan Hidup dan Kehutanan) diangkat

44 EITIIndonesia, "Perpres No 26 Tahun 2010", diakses 25 Mei 2017, eiti.ekon.go.id/perpres-26-2010/?aid=262\&sa $=1$.

45 Tempo Online, "Wapres Boediono Buka Konvensi dan Pameran Migas IPA ke-34", diakses 29 Mei 2010, https://m.tempo.co/read/news/2010/05/19/140248735/ wapres-boediono-buka-konvensi-dan-pameran-migasipa-ke-34. untuk menjadi Ketua EIR, yang dapat dikatakan merupakan tunas bagi tumbuhnya gagasan mengenai transparansi industri ekstraktif di Indonesia. Sementara Boediono yang pada saat itu merupakan Menteri Keuangan juga diangkat menjadi Governor dalam WBG, yang kemudian memiliki peran sebagai penyedia dana bagi EITI melalui inisiasi MDTF. Baik Prof. Emil Salim dan Boediono memiliki karir kepemerintahan yang terus menanjak dan krusial dalam pengambilan keputusan dari lembaga eksekutif. Setelah menjadi Menteri Lingkungan Hidup dan Kependudukan, Prof. Emil Salim diangkat menjadi anggota tim penasihat presiden dan kemudian menjadi kepala dewan pertimbangan presiden. Boediono setelah menjadi Menteri Keuangan juga menjadi Menteri Koordinator bidang Perekonomian dan menjadi Wakil Presiden RI.

Keikutsertaan Prof. Emil Salim dan Boediono dalam proyek-proyek Bank Dunia telah menanamkan pandangan yang sejalan dengan Bank Dunia. Kedudukan Prof. Emil Salim dan Boediono yang selalu didalam lingkaran pengambil keputusan juga berperan signifikan bagi diterimanya gagasan ini oleh pemerintah Indonesia. Kedudukan Prof. Emil Salim dan Boediono sebagai bagian dari pemerintah Indonesia yang dalam saat bersamaan juga memiliki keanggotaan dalam proyek Bank Dunia menggambarkan kooptasi elit dalam kelima fitur hegemoni Cox. Hal ini didasarkan pada keadaan dimana hasil EIR yang diketuai oleh Prof. Emil Salim pada akhirnya menunjukkan keberpihakannya kepada Bank Dunia. Kemudian ketika kritik bermunculan, Boediono menyampaikan pernyataan atas nama pemerintah Indonesia yang mendukung EITI. Prof. Emil Salim juga berperan sebagai perantara pihak Bank Dunia dan EITI pada rapat koordinasi dengan Kementerian Koordinator Perekonomian. Boediono sendiri saat menjadi Menteri Koordinator bidang Perekonomian mendorong penerbitan Instruksi Presiden Nomor 5 tahun 2008 terkait transparansi pendapatan industri minyak dan pertambangan. Pada akhirnya, promosi gagasan transparansi 
industri ekstraktif membutuhkan dukungan elit-elit yang berperan kuat dalam pengambilan keputusan dan pembuatan regulasi untuk 2 alasan, yakni 1) membuat gagasan tersebut diterima oleh elit-elit pemerintah lainnya dan 2) mendapatkan dukungan dari pemimpin negara, lembaga negara, maupun masyarakat.

\section{Intitusi Menyerap Gagasan-Gagasan Kontra Hegemoni}

Fitur terakhir dari hegemoni menurut Cox adalah diserapnya bibit-bibit ide kontra hegemoni dan kemudian membuat ide-ide ini berjalan konsisten dengan doktrin hegemoni. Menurut Cox, hegemoni akan selalu berhasil mengesampingkan usaha-usaha untuk mengubah struktur tatanan dunia karena keterhubungannya dengan kekuatan hegemon nasional dan memiliki basis yang kuat terutama di negara-negara periferal. ${ }^{46}$

Ada setidaknya 2 organisasi masyarakat sipil yang mengkritik EIR di Indonesia, yakni Wahana Lingkungan Hidup (WALHI) dan Yayasan Pemberdayaan dan Advokasi Perempuan dan Anak (PUSPA). ${ }^{47}$ Perwakilan dari kedua organisasi ini melakukan kajian bersama dengan organisasi masyarakat sipil lain diluar Indonesia dan menyimpulkan bahwa EIR telah gagal merefleksikan isu-isu yang justru menjadi perhatian terbesar masyarakat sipil. Melalui Asia-Pacific Civil Society Statement of Withdrawal From The Extractive Industries Review Process yang dipubliksikan pada tanggal 27 April 2003, 14 organisasi masyarakat sipil menyatakan kekecewaan terhadap EIR. EIR dinilai tidak sama sekali membicarakan isu kebijakan structural adjustment dan dampaknya pada sektor ekstraktif. Organisasi masyarakat yang tergabung menyerukan kekecewaan karena perubahan yang dibawa oleh EIR justru tidak mewakili seruan organisasi masyarakat sipil yang tergabung. Kritik lain adalah

46 Cox, "Gramsci, Hegemony, and International Relations", 139.

47 Friends of the Earth International, "Asia-Pacific Civil Society Statement Of Withdrawal From The Extractive Industries Review Process", diakses 19 Mei 2017, http://members.foei.org/en/what-we-do/mining/global/ extractive-industries-review/rio.html. mengenai tidak adanya keterbukaan mengenai alur konsultasi dengan perwakilan masyarakat lokal yang terkena dampak industri migas dan pertambangan (affected communities) pada tahap perencanaan awal keterlibatan lembaga keuangan dalam industri ekstraktif. ${ }^{48}$ Namun pada kelanjutan perkembangan gagasan transparansi industri ekstraktif, kritik-kritik dari organisasi sosial masyarakat tidak muncul kembali. WALHI dan PUSPA pun saat ini mendukung EITI dengan menjadi anggota PWYP. ${ }^{49}$

EITI memiliki skema grup multipihak, yang terdiri dari lembaga pemerintah yang ditunjuk, organisasi perusahaan, serta grup masyarakat sipil. PWYP menjadi satu-satunya perwakilan dalam grup masyarakat sipil EITI. Hal tersebut dianggap wajar karena PWYP terdiri dari 35 organisasi masyarakat sipil yang tergabung di dalamnya, termasuk NRGI, IESR, WALHI, dan PUSPA yang telah penulis singgung sebelumnya. PWYP Indonesia terus menambah anggota dari organisasi masyarakat lokal. Bagi PWYP, hal ini dimaksudkan untuk mengadvokasi kepentingan publik atas transparansi industri ekstraktif diluar koalisi dan keanggotaan PWYP. ${ }^{50}$ Namun penulis melihat hal ini sebagai cara PWYP untuk semakin memperluas blok historis, dimana organisasi masyarakat sipil yang menjadi anggota PWYP juga akan menyebarkan gagasan dan pengertian yang sejalan dengan pandangan Bank Dunia, sebagaimana PWYP dan EITI. Koalisi PWYP yang terus bertambah akan menguntungkan bagi penyebaran EITI itu sendiri karena semakin banyaknya pihak-pihak yang memperkuat dorongan bagi ide tersebut. Tidak berhenti pada adopsi EITI, pihak-pihak tersebut juga akan membantu mendorong fiturfitur keterbukaan baru bagi gagasan transparansi

48 Cox, "Gramsci, Hegemony, and International Relations", 139.

49 PWYP Indonesia ,"PWYP - members and partners", diakses 19 Mei 2017, http://pwyp-indonesia.org/en/ members-and-partners/.

50 "Joint Review, EITI and EITI Multi-donor Trust Fund Resourcing of EITI", diakses 24 Mei 2017, https:// scanteam.no/2016-06-09-12-31-45/2014/222-jointreview-eiti-and-eiti-multi-donor-trust-fund-resourcingof-eiti. 
industri ekstraktif sesuai dengan ide-ide yang dikampanyekan PWYP.

Sebagai perwakilan masyarakat sipil, PWYP berhak memilih 3 orang untuk menjadi perwakilan masyarakat sipil selama periode 3 tahun dalam tim pelaksana EITI yang kemudian akan diangkat dan diberhentikan oleh Ketua Tim Pengarah. ${ }^{51}$ PWYP juga berhak memberikan usulan perwakilan masyarakat sipil dalam komposisi dewan pengawas, yang sampai saat ini masih ditempati oleh Emil Salim. Kedudukan PWYP sebagai organisasi masyarakat sipil yang berhak memilih perwakilan untuk duduk dalam grup multipihak EITI memberikan ruang yang besar bagi PWYP untuk memastikan bahwa perwakilan tersebut membawa ide yang sejalan dengan pandangan blok historis pada tingkat global. Pendapat penulis tersebut didasari pada kesamaan ide yang didorong oleh PWYP dengan yang didorong oleh Bank Dunia untuk diterapkan oleh pemerintah Indonesia, salah satunya pada pengaturan-pengaturan baru dalam EITI.

Sebagaicontoh, saatini, langkah keterbukaan yang akan ditempuh oleh EITI Indonesia adalah mengenai keterbukaan kontrak pertambangan dan migas (contract disclosure). ${ }^{52}$ Pengaturan ini dipaparkan oleh Bank Dunia kepada Team Leader EITI Indonesia..53 Gagasan mengenai keterbukaan kontrak ini juga telah digaungkan oleh PWYP sebagai perwakilan masyarakat sipil sejak tahun 2013 melalui "Endorsement Letter PWYP Indonesia terhadap Perbaikan Standar EITI Global” yang ditujukan kepada pemerintah Indonesia. Dalam surat tersebut, PWYP meminta pemerintah Indonesia mewajibkan pembukaan kontrak-kontrak industri ekstraktif melalui suatu website resmi yang dapat diakses secara bebas. ${ }^{54}$

51 Perpres no. 26 tahun 2010 tentang Transparansi Pendapatan Negara dan Pendapatan Daerah yang Diperoleh dari Industri Ekstraktif, diakses 16 November, 2017, eiti.ekon.go.id/perpres-26-2010/?aid=262\&sa $=1$.

52 Edi Effendi, Team Leader EITI Indonesia, wawancara di Kantor Kementerian Perekonomian RI pada 15 Mei 2017.

53 Edi Effendi, 2017.

54 Faisal Basri, "Endorsement Letter PWYP Indonesia terhadap Perbaikan Standar EITI Global, 15 Januari 2013, diakses 24 Mei 2017, https://m.facebook.com/ PublishWhatYouPayIndonesia/posts/478274872209130.
Sementara pada posisi pemerintah Indonesia sendiri, pemerintah masih ragu untuk menerapkan keterbukaan kontrak dalam EITI karena masih merasa penerapannya belum bersifat equal treatment dan karena terdapatnya resistensi dari Kementerian Energi dan Sumber Daya Mineral (ESDM). ${ }^{55}$ Pemerintah Indonesia merasa bahwa dorongan EITI selalu dimulai oleh negara-negara berkembang terlebih dahulu, sementara negara-negara maju, termasuk tujuh negara maju pendukung gagasan transparansi (negara-negara supporter EITI) menerapkannya belakangan atau belum memulai mengarah kesana sama sekali. Menurut pemerintah Indonesia, keterbukaan kontrak hanya akan berpengaruh positif jika dilakukan bersama-sama. Sedangkan bila dilakukan secara parsial malah akan membawa keuntungan bagi pihak yang tidak membuka kontrak karena mengetahui strategi lawan. ${ }^{56}$ Bagi pemerintah Indonesia, keterbukaan merupakan hal yang baik, akan tetapi untuk suatu hal yang bersifat rahasia, boleh untuk tidak dibuka, tidak perlu dorongan terus menerus untuk dibuka. ${ }^{57}$

Pada akhirnya menurut penulis, grup multipihak dalam EITI merupakan bagian dari blok historis itu sendiri. Grup multipihak EITI sendiri yang akan meredam bibit-bibit ide kontra hegemoni dan kemudian membuat ide-ide ini berjalan konsisten dengan doktrin hegemoni. Anggapan tersebut didasarkan pada keadaan dimana perwakilan masyarakat sipil yang terdapat pada EITI juga merupakan anggota dari blok historis Bank Dunia dalam penyebaran gagasan EITI. Ketimbang merepresentasikan keterwakilan, menurut penulis, grup multipihak ini justru menjadi instrumen pendukung untuk menekan pemerintah Indonesia melakukan kebijakan-kebijakan tertentu. Kebijakankebijakan dalam EITI seolah tidak hanya datang dari institusi internasional, namun juga dari perwakilan masyarakat sipil. Padahal, perwakilan masyarakat sipil yang dimaksud memang sejak awal memiliki pandangan yang

Edi Effendi, 2017.

Edi Effendi, 2017.

Edi Effendi, 2017. 
sejalan dengan institusi internasional yang dimaksud. Pemerintah masih dapat memiliki skeptisisme terhadap gagasan Bank Dunia. Namun, lain halnya jika gagasan tersebut dibawa oleh perwakilan masyarakat sipil, akan terlihat tidak beralasan bagi pemerintah untuk berpikir bahwa 'permintaan rakyat akan digunakan untuk kepentingan negara lain'. Padahal, jika melihat lebih mendalam, perwakilan masyarakat sipil dalam EITI juga adalah bagian dari blok historis Bank Dunia.

Sementara perwakilan sektor swasta dalam EITI Indonesia terdiri dari MNC seperti BP Indonesia, China National Oil Offshore Corporation (CNOOC), International Petroleum Exploration Corporation (INPEX), dan Petrochina. Perwakilan ini berhak menentukan format laporan (reporting template). ${ }^{58}$ Perusahaan ini adalah anak-anak perusahaan yang terbukti mendapatkan keuntungan material semakin besar dari adanya EITI, yang telah penulis singgung pada penjelasan sebelumya terkait EITI dan investasi luar negeri di Kazakhstan. Perusahaan anak ini akan cenderung mengikuti kebijakan perusahaan induknya di dalam negeri. Sementara perusahaan migas minerba di dalam negeri akan terdorong untuk menerapkan EITI karena menyangkut citra perusahaan dan juga tekanan dari perusahaan global pesaingnya yang telah menerapkan.

Pada akhirnya penulis melihat bahwa pihak-pihak yang mewakili pemerintah, sektor swasta, maupun masyarakat sipil dalam tim multipihak EITI merupakan pihak yang pada dasarnya merupakan bagian dari blok historis dalam penyebaran gagasan industri ekstraktif. Meskipun Bank Dunia tidak secara langsung menjadi bagian dalam tim multipihak EITI, tim multipihak dalam EITI telah memiliki pandangan dan arah berpikir yang sejalan dengan Bank Dunia secara garis besar. Pandangan yang sama ini disebabkan karena pada skala global, pihak-pihak yang terlibat dalam tim multipihak EITI Indonesia telah

58 Revenue Watch Institute, "2010 Revenue Watch Index”, diakses 25 Mei 2017, http://www.revenuewatch.org/ rwindex2010/pdf/RevenueWatchIndex_2010.pdf. menjadi bagian dalam blok historis yang turut menyebarkan gagasan transparansi industri ekstraktif bersama Bank Dunia.

\section{KESIMPULAN}

Melalui pembahasan diatas, dapat disimpulkan bahwa diterima dan diimplementasikannya gagasan transparansi industri ekstraktif di Indonesia terjadi melalui proses hegemoni intelektual. Gramsci menekankan hegemoni intelektual pada 2 hal, yakni 1) kekuatan ideologis untuk mencapai hegemoni dan 2) blok historis sebagai kekuatan utama dalam penyebaran gagasan. Mekanisme penerimaan dan implementasi EITI merupakan ide yang berasal dari pertemuan negara-negara G8 dengan Inggris, Amerika Serikat, dan Jerman sebagai pendukung utamanya. Meskipun pada awalnya negara yang mengusulkan gagasan ini belum menerapkan EITI, mereka berhasil membuat negaranegara Afrika mengimplementasikan gagasan tersebut secara sukarela. Peletakan EITI sebagai komponen dari konsep good governance menjadi alasan utamanya. Hal ini berpengaruh pada reputasi negara seandainya tidak menjalankan EITI karena reputasi yang buruk bagi negara berkembang akan menghambat akses mereka terhadap kesempatan kerjasama dengan negara maju maupun berbagai institusi keuangan internasional. EITI seolah menjadi representasi akuntabilitas negara sehingga akan mempengaruhi kepercayaan pihak lain dalam hubungan bilateral maupu multilateral. Meskipun tanpa paksaan, penerimaan dan implementasi EITI menjadi tidak terhindarkan karena menyangkut kepentingan strategis negara. Manipulasi ideologis ini membuat negara-negara berkembang dapat secara sukarela menerima dan mengimplementasikan EITI.

Kedua, gagasan EITI dipromosikan secara besar-besaran oleh berbagai pihak yang memiliki andil besar dalam sistem internasional-pada istilah Gramsci merujuk pada blok historis. Tidak hanya oleh negara maju, tetapi juga institusi keuangan terbesar 
yakni Bank Dunia dan IMF yang memberikan set bantuan berupa bantuan dana, teknis, dan pengawasan, melalui dana yang dihimpun dari negara-negara maju. Aktor-aktor tersebut tidak hanya beroperasi pada level global, namun juga mengawal promosi pada level domestik hingga suatu gagasan dapat diterima oleh pemerintah negara. Ditempatkannya EITI champion sangat mempermudah penerimaan gagasan tersebut pada level domestik. Tokoh EITI champion merupakan orang-orang yang pemikirannya dan nasihatnya memiliki pengaruh besar dalam keputusan presiden sebagai pemimpin negara. Tidak hanya bergerak secara top down, blok historis juga bergerak secara bottom up dengan mengarahkan opini masyarakat untuk mendorong pemerintahnya menerapkan EITI. Hal ini dilakukan melalui keberadaan institusi non pemerintah seperti PWYP yang memposisikan dirisebagaipenghimpundan wakil suara masyarakat. PWYP dalam menyebarkan gagasan EITI bergerak melalui setidaknya 3 cara. Pertama, dengan menerbitkan jurnal maupun membuat seminar yang menargetkan langsung kepada masyarakat. Kedua, dengan menghimpun organisasi non-pemerintah lokal yang akan menyebarkan nilai-nilai yang sejalan dengan PWYP. Ketiga, PWYP turut mendorong bentuk-bentuk keterbukaan pendapatan migas dan minerba yang sejalan dengan saran Bank Dunia kepada pemerintah Indonesia. Cara ketiga tidak mengherankan karena PWYP pada tataran global memang mendukung dan menopang EITI sejak awal. PWYP bergerak secara progresif bersamaan dengan penerapan EITI melalui Bank Dunia di berbagai negara.

Selain membuktikan dua premis utama Gramscian, institusionalisasi EITI juga membuktikan 5 fitur hegemoni sebagai berikut. Pertama, EITI membantu ekspansi hegemoni dalam tatanan dunia dimana transparansi memang sejalan dengan kebutuhan iklim perdagangan bebas untuk menganalisis prediktabilitas pasar yang dirumuskan oleh World Trade Organization (WTO) dalam Putaran Doha pada tahun 2011. Kedua, EITI sendiri merupakan produk dari hegemoni karena mewakili ide-ide dari negara-negara G8 yang mendorong adopsi ide oleh pihak yang secara struktural lebih lemah melalui Bank Dunia dan IMF. Ketiga, proses penyebaran gagasan EITI membantu mengesahkan norma-norma tatanan dunia melalui peletakan EITI dalam komponen good governance dan disebarluaskan oleh blok historis yang beranggotakan berbagai institusi keuangan internasional, lembaga riset, NGO, maupun lembaga donor. Keempat, masuknya EITI kedalam suatu negara melalui proses kooptasi elit pada negara periferal dengan sistem EITI champion. Elit-elit pemerintahan yang memiliki peran penting dalam pengambilan keputusan ditempatkan dalam keorganisasian Bank Dunia sehingga memiliki pandanganpandangan yang sejalan dengan Bank Dunia. EITI champion tersebut kemudian berkomitmen menyebarkan gagasan EITI kepada lembaga pemerintah hingga diterima, disahkan, dan diterapkan secara legal. Terakhir, kelima, EITI sendiri merupakan institusi yang mampu menyerap gagasan-gagasan kontra hegemoni melalui grup multipihak didalamnya. Elemen grup multipihak yang ada dalam EITI pada dasarnya merupakan pihak-pihak yang memiliki keterkaitan dengan pihak-pihak didalam blok historis penyebaran gagasan EITI. Hal ini memungkinkan grup multipihak memiliki peran selain menjadi perwakilan pemerintah, bisnis, dan masyarakat, yakni menjadi peredam tanggapan kritis maupun kontra yang datang dari ketiga sektor diatas. 


\section{DAFTAR PUSTAKA}

\section{Buku}

Cox, Robert W. Production, Power, and World Order: Social Forces in the Making Of History. Vol.1. Columbia: New York: Columbia University Press, 1987.

Barry, Dalal-Clayton, dan Barry Sadler. Sustainability Appraisal: A Sourcebook And Reference Guide To International Experience. London: Routledge, 2014.

Bernard, Finel., and Kristin Lord, Power and Conflict in the Age of Transparency. (New York: Springer, 2002), 3.

Fitriani, Evi., Francisia SSE Seda, dan Yesi Maryam. eds. Governance of Extractive Industries: Assessing National Experiences to Inform Regional Cooperation in Southeast Asia. Jakarta: UIP, 2014

Sugiono, Muhadi. Kritik Antonio Gramsci Terhadap Pembangunan Dunia Ketiga. Yogyakarta: Pustaka Pelajar, 1999.

Tomz, Michael. Reputation And International Cooperation: Sovereign Debt Across Three Centuries. New Jersey: Princeton University Press, 2012

"Indonesia : 2008 Article IV Consultation-Staff Report; Staff Statement; Public Information Notice on the Executive Board Discussion; and Statement by the Executive Director for Indonesia', IMF Country Report No. 08/299, 2008 International Monetary Fund, https:// books.google.co.id/books?id=VuqTEI DWE4C\&pg $=$ PA58\&lpg $=$ PA58\&dq $=$ ei $\mathrm{ti}+$ indonesia $+2008 \&$ source $=\mathrm{bl} \&$ ots $=\mathrm{W}$ mxd_HBDSM\&sig $=y$ U9H4-7LZHkZGSX zepqarVJHT1g\&hl $=$ en\&sa $=X \&$ ved $=0 \mathrm{ah}$ UKEwiFyvOJOa_TAhULpI8KHRSQBaU Q6AEITDAH\# $\bar{v}=$ onepage $\& q \& f=$ false.

\section{Jurnal}

Alam, Azi Nur. "Kepentingan World Bank dan Pemerintah Indonesia dalam Proses Pengimplementasian Extractive Industries Transparency Initiative (EITI)", (Program Studi S2, Universitas Indonesia, 2010).

Aaronson, Susan Ariel., "Limited partnership: Business, government, civil society, and the publicin the ExtractiveIndustries Transparency Initiative (EITI)". Public Administration and Development 31, no. 1 (2011): 50.

Auty, Richard M. "Industrial Policy Reform in Six Large Newly Industrializing Countries: The Resource Curse Thesis." World development 22, no. 1 (1994): 11-26.

Cox, Robert W. "Gramsci, Hegemony And International Relations: An Essay In Method." Millennium 12, no. 2 (1983), 133.

Erickson, Jennifer L. "Saving Face, Looking Good, And Building International Reputation In East And West." Power in a Complex Global System (2014).

Keblusek, Mary Ella dan Nigeria's, E. I. T. I., "Is EITI Really Helping Improve Global Good Governance?", (2010).

Laksmini, Gita Widya. Maryati Abdullah, "EITI in Indonesia: A Multi-Stakeholder Advocacy", RWI-USAID IKAT US Project, (2012): 2.

Oranje, Mabel van. dan Henry Parham, "Publishing What We Learned", assesment of the Publish What You Pay Coalition (2009), 32.

Sadvakassov, Darmen., Serik Orazgaliyev. "Key Factors In Attracting Foreign Direct Investments In The Oil And Gas Industry Of Kazakhstan." Aktual'ni Problemy Ekonomiky = Actual Problems in Economics 166 (2015), 147.

Schmaljohann, Maya. "Enhancing Foreign Direct Investment via Transparency? Evaluating the Effects of the EITI on FDI". No. 538. Discussion Paper Series, University of Heidelberg, Department of Economics, (2013): 18.

Transparency Initiative, “GPR.” (2011). 
Nigeria's, E. I. T. I. dan Mary Ella Keblusek, "Is EITI Really Helping Improve Global Good Governance?", (2010), 3.

World Bank, EITI Implementation Report 2010 (World Bank: February 2010), 4.

\section{Website}

Blair, Tony., "Extractive Industries Transparency Initiative", (pidato, Johannesburg, Afrika Selatan, 17 Juni 2003), Europe Archive, diakses 30 Juli 2017, http://collections.europarchive.org/ tna/20070701080507/http:/www.dfid.gov. uk/pubs/files/eitidraftreportspeech.pdf.

Badan Pengawas Keuangan dan Pembangunan, "Instruksi Presiden nomor 5 tahun 2008 tentang Fokus Program Ekonomi tahun 2008-2009", diakses 21 Mei 2017, www. bpkp.go.id/uu/filedownload/7/24/37.bpkp.

“2010Revenue Watch Index” diakses25 Mei2017, http://www.revenuewatch.org/rwindex2010/ pdf/RevenueWatchIndex_2010.pdf

"Extractive Industries Transparency Initiative", (pidato, Johannesburg, Afrika Selatan, 17 Juni 2003), Europe Archive, diakses 30 Juli 2017, http://collections.europarchive.org/ tna/2007070 1080507/http:/www.dfid.gov. uk/pubs/files/eitidraftreportspeech.pdf.

EITI Indonesia, "Perpres no 26 tahun 2010", diakses 25 Mei 2017, eiti.ekon.go.id/ perpres-26-2010/?aid $=262 \&$ sa $=1$.

EITI Organization, "EITI in Kazakhstan, Kyrgyzstan and possibly Tajikistan", diakses 5 Mei 2017, https://eiti.org/blog/eiti-inkazakhstan- kyrgyzstan-possibly-tajikistan.

EITI Organization, "Joint Review, EITI and EITI Mutli-donor Trust Fund Resourcing of the EITI", diakses 20 Mei 2017 https:/eiti. org/sites/default/files/.../2015_ScanteamReview_EITI-Funding.pdf.

"EITI: Multistakeholder persepectives", PWYP Indonesia, diakses 30 Juli 2017, http://pwypindonesia.org/id/164780/menggali-sejarahinisiatif-transparansi-industri-ekstraktif/.
EITI Organization, "Possibilities for Armenia", diakses 5 Mei 2017, http://crm.aua.am/ files/2014/10/EITI-and-CSOs.pdf.

EITI Organization, "Southeast Asia Warming Up to EITI", diakses 23 Februari 2017, https://eiti.org/blog/southeast-asiawarming-up-to-eiti.

EITI Organization, "Prinsip-Prinsip EITI", diakses 5 Mei 2017, https://eiti.org/ document/eiti-principles.

Faisal Basri, "Endorsement Letter PWYP Indonesia terhadap Perbaikan Standar EITI Global, 15 Januari 2013, diakses 24 Mei 2017, https://m.facebook. com/PublishWhatYouPayIndonesia/ posts/478274872209130.

Friends of the Earth International, "Asia-Pacific Civil Society Statement of Withdrawal From The Extractive Industries Review Process", diakses 19 Mei 2017, http:// members.foei.org/en/what-we-do/mining/ global/extractive-industries-review/rio. html.

Hamilton, Kirk \& Giovanni Ruta, "From Curse to Blessings", Environment Matters 2006The World Bank Group, 2006, diakses 14 November 2017, http://siteresources. worldbank.org/INTENVMAT/641999551162240805462/21125342/9FromCurse.pdf.

GOXI web-site, "About Us”, diakses pada 20 Mei 2017, www.goxi.org/page/about-us.

International Monetary Fund, "Indonesia : 2008 Article IV Consultation-Staff Report; Staff Statement; Public Information Notice on the Executive Board Discussion; and Statement by the Executive Director for Indonesia', IMF Country Report No. 08/299, 2008, diakses 30 Mei 2017, https://books. google.co.id/books?id=VuqTEI_DWE4C $\& p g=$ PA58\&lpg $=$ PA58\&dq $=$ eiti + indon esia $+2008 \&$ source $=$ bl\&ots $=$ Wmxd_HB DSM\&sig $=y$ U9H47LZHkZGSXzepqarVJ HTlg\&hl=en\&sa $=$ X\&ved $=0$ ahUKEwiF yvOJ0a_TAhULpI8KHRSQBaUQ6AEIT $\mathrm{DAH \#}_{\mathrm{v}}=$ onepage $\& \mathrm{q} \& \mathrm{f}=$ false. 
Japan Ministry of Foreign Affairs, "Fighting Corruption and Improving Transparency: A G8 Declaration", diakses 12 Mei 2017, www.mofa.go.jp/policy/economy/ summit/2003/dec-2.pdf.

"Joint Review, EITI and EITI Multi-donor Trust Fund Resourcing of EITI", diakses 24 Mei 2017, https://scanteam.no/2016-06-09-1231-45/2014/222-joint-review-eiti-and-eitimulti-donor-trust-fund-resourcing-of-eiti.

Natural Resoure Governance Institute, "Publications", diakses 16 Mei 2017, https://resourcegovernance.org/analysistools/publications.

Open Library World Bank, "Open Knowledge Repository", diakses 16 Mei 2017, https:/ openknowledge.worldbank.org/discover?sc ope $=\% 2 \mathrm{~F} \&$ query $=$ resource + curse $\&$ subm it.

Perpres no. 26 tahun 2010 tentang Transparansi Pendapatan Negaradan Pendapatan Daerah yang Diperoleh dari Industri Ekstraktif, diakses 16 November, 2017, eiti.ekon. go.id/perpres-26-2010/?aid=262\&sa $=1$.
Publish What You Pay Indonesia "Publications", diakses 16 Mei 2017, http://pwyp-indonesia. org/id/category/publikasian/page/11/.

PWYP Indonesia ,PWYP_ members and partners", diakses 19 Mei 2017, http:// pwyp-indonesia.org/en/members-andpartners/.

Revenue Watch Institute, "2010 Revenue Watch Index", diakses 25 Mei 2017, http:// www.revenuewatch.org/rwindex2010/pdf/ RevenueWatchIndex 2010.pdf.

Tempo Online, "Wapres Boediono Buka Konvensi dan Pameran Migas IPA ke-34", diakses 29 Mei 2010, https://m.tempo.co/ $\mathrm{read} /$ news/2010/05/19/140248735/wapresboediono-buka-konvensi-dan-pameranmigas-ipa-ke-34.

\section{Wawancara}

Edi Effendi, Team Leader EITI Indonesia, wawancara di Kantor Kementerian Perekonomian RI pada 15 Mei 2017. 